\title{
O mundo natural e o erotismo das gentes no Brasil Colônia: a perspectiva do estrangeiro
}

\author{
Jean Marcel Carvalho França
}

Nas últimas décadas do século XVIII, o americano Thomas Jefferson tornou-se uma personagem da moda em Paris, ${ }^{1}$ o renomado naturalista francês Georges-Louis Leclerc, conde de Buffon, e o polêmico pensador holandês Corneille de Pauw sentiam-se suficientemente informados acerca do Novo Mundo para, sem nunca terem estado lá, defenderem a sua polêmica tese de que a América era um continente fraco e imaturo, ${ }^{2}$ François-René de Chateaubriand, inspirado nas narrativas de viagem de James Cook e Bougainville, preparava o seu célebre Atala (1801) - narrando as peripécias amorosas vividas por um europeu americanizado (René) e uma índia americana cristianizada (Atala) ${ }^{3}$ - e os membros da Academia de Ciências, Belas-letras e Artes de Lion avaliaram que a América era um tema suficientemente conhecido dos seus sócios e colaboradores e não hesitaram em lançar, no ano de 1782, um concurso de monografias que tinha como tema, proposto por ninguém menos do que o abade Raynal, a seguinte questão: “A descoberta da América foi útil ou perniciosa para o gênero humano?". Tema, sem dúvida, bastante complexo, que pressupunha um razoável conhecimento sobre a América e sobre a sua história por parte daqueles que desejassem conquistar os 1.200 francos oferecidos como prêmio ao primeiro colocado. ${ }^{4}$ Tamanha "familiaridade" provinha de três séculos de constante tematização do Novo Mundo, de constante, ainda que com intensidade variável ao longo do tempo, ${ }^{5}$ empenho dos povos europeus em construir um vocabulário sobre a América, um vocabulário capaz de dar a conhecer - e conhecer significa, naturalmente, dispor de meios para agir sobre - os aspectos físicos, naturais e humanos do continente que se interpunha entre o Oriente e o Ocidente. Os escritos que alimentaram essa vontade de conhecer, nomear e intervir dos europeus são muitos e de natureza variada: vão da Utopia (1506), de Thomas More, ao Discours sur la question proposée par M. l'abbé Raynal (1790), de um tal senhor Carle, um dos participantes do citado concurso promovido na cidade de Lion em 1782.

Malgrado, no entanto, a sua variedade, essa longa série de escritos sobre a América apresenta, pelo menos, uma constante. Romancistas, poetas e pintores, filósofos e polemistas, cartógrafos, geógrafos, naturalistas e historiadores do Novo Mundo, em suma, senão todos, a esmagadora maioria daqueles que, em verso, prosa ou imagens, propagaram pela Europa notícias sobre o Novo Mundo lançaram mão, com mais ou menos intensidade, de um mesmo conjunto documental: as narrativas de viagens. A bem da verdade, boa parte do que os europeus escreveram sobre o mundo de além-mar - sobre a América, mas também sobre a África, a Índia, a China, o Japão, as terras do Pacífico Sul, a Austrália etc. -, durante pelo menos os três séculos que se seguiram à viagem de Colombo, baseou-se em relatos de viagem, em relatos de aventureiros e exploradores que, muitas vezes à custa da própria vida, viram com os próprios olhos ou disseram que viram - aquelas terras que tanto atiçavam a imaginação dos seus contemporâneos.

O Brasil, ainda que com menos intensidade ${ }^{6}$ do que outras partes do mundo que também eram novas para os europeus, não escapou a esse processo. Ao contrário, diante do famigerado mutismo português, a esmagadora maioria do que circulou sobre a colônia portuguesa na América Austral em terras europeias, a partir da metade do século XVI, buscou inspiração e informação em narrativas de viagem de estrangeiros, de não portugueses. Há, pois, poderíamos mesmo dizer, um Brasil construído na literatura de viagens que alimentou o senso comum europeu. O que pretendo aqui é traçar um ligeiro esboço de uma parcela muito pequena desse vocabulário que inventou, para o público europeu, o Brasil dos tempos da colônia, aquela parcela relativa ao mundo natural e à conduta erótica do colono.

Grosso modo, quais eram os contornos do Brasil e dos seus habitantes para os relativamente poucos ${ }^{7}$ europeus que o visitaram, e que escreveram sobre a visita, durante os três séculos subsequentes ao desco- 
brimento? Em linhas gerais, a quase totalidade das descrições da colônia deixadas por viajantes estrangeiros inclinou-se a contrapor, desde muito cedo, a exuberância e a prodigalidade da terra ao caráter vicioso e corrompido dos seus habitantes. Mas partamos do princípio, partamos de Vespúcio. O "corrido" navegador florentino, na sua renomada Mundus Novus, de 1503, depois de explicar ao seu destinatário, Lorenzo di Médici, a natureza da estranha gente que encontrou nas novas terras, comentou: "ali o ar é muito temperado e bom e, pelo que pude conhecer [...], nunca houve peste ou outra doença oriunda da corrupção do ar". ${ }^{8}$ Um pouco mais adiante, o navegador complementa:

A terra daquelas regiões é muito fértil e amena, com muitas colinas, montes, infinitos vales, abundante em grandíssimos rios, banhada de saudáveis fontes, com selvas amplíssimas e densas, pouco penetráveis, copiosa e cheia de todo o gênero de feras. Ali principalmente as árvores crescem sem cultivador, muitas das quais dão frutos deleitáveis no sabor e úteis aos corpos humanos [...]. Se quisesse lembrar de cada coisa que ali existe e escrever sobre os numerosos gêneros de animais e a multidão deles, a coisa se tornaria totalmente prolixa e imensa [...].

Ali todas as árvores são odoríferas e cada uma emite de si goma, óleo ou algum líquido cujas propriedades, se fossem por nós conhecidas, não duvido de que seriam saudáveis aos corpos humanos. Certamente, se o paraíso terrestre estiver em alguma parte da terra, creio não estar longe daquelas regiōes, cuja localização [...] é para o meridiano, em tão temperado ar que ali nunca há invernos gelados nem verões férvidos. ${ }^{9}$

Fertilidade da terra, variedade da fauna, exuberância da flora e clima salubre, livre dos rigores do inverno europeu, eis os pilares da descrição de Vespúcio, pilares que se perpetuarão nas narrativas de viagem sobre o Brasil, quando o tema abordado for a natureza local. Indícios do paraíso? Por certo. Entretanto, não exageremos em demasia a importância de tal caracterização e, sobretudo, não percamos de vista que, no tocante aos relatos de viagem sobre o Brasil, a metáfora do "paraíso" perde muito de sua contundência e tem o seu uso bastante reduzido a partir da segunda metade do século XVI.

$\mathrm{O}$ que não perdeu o vigor comunicativo ao longo dos séculos foram os quatro pontos abordados por Vespúcio. O clima ameno, por exemplo. Nicolas Barré, que desembarcou na baía de Guanabara em 1576, diz ter se surpreendido com a temperatura que encontrou na então denominada "zona tórrida”, onde esperava se deparar com um calor capaz até mesmo de comprometer a vida de um europeu: "[...] ao contrário do que diziam os antigos, pareceu-nos bastante temperada, de tal modo que os homens que estavam vestidos não precisaram de se despir e os que estavam despidos não careceram de se cobrir". ${ }^{10}$ Também surpreendidos com o anunciado clima ameno da baía de Guanabara ficaram outros dois colegas de Barré na aventura da França Antártica, Jean de Léry e André Thévet. O calvinista Léry, sobretudo, que por quase 12 meses viveu em terra, na companhia de alguns camaradas e dos nativos, empenhou-se, inclusive, em esclarecer aos seus coetâneos que os índios, fisicamente, não apresentavam grandes diferenças dos europeus - "não são maiores nem mais gordos" -, mas eram "mais fortes, mais robustos, mais entroncados, mais bem dispostos e menos sujeitos à moléstia”, virtudes que, segundo o calvinista, decorriam do modo de vida despreocupado dos nativos e do "bom clima da terra, sem geadas nem frios excessivos que perturbam o verdejar permanente dos campos e da vegetação [...]" ${ }^{11} \mathrm{O}$ célebre prisioneiro Hans Staden não desceu a considerações tão sutis, já que a sua situação não o permitia, mas ainda assim não deixou de registrar: "Na parte da terra que fica entre os trópicos, em nenhum tempo do ano faz frio, como aqui, no dia de São Miguel, mas a terra ao sul do trópico de Capricórnio é um pouco mais fria". ${ }^{12}$

Ao longo do século XVII, a tópica do clima ameno e salubre propagada por Vespúcio, ainda que tenha em larga medida deixado de lado a metáfora do "paraíso" - a metáfora da "primavera eterna" começa a tomar o seu lugar -, não abandona as narrativas de viagem sobre o Brasil e ainda é alvo de poucas contestações. Havia já, no entanto, contrariamente ao século XVI, quem não tomasse o clima local por agradável, por temperado. Em 1649, o aventureiro inglês Richard Flecknoe, que se gabava de ter sido o primeiro "turista" a pisar em terras cariocas, comenta: o clima do "país é quente e, devido às chuvas 
abundantes e contínuas, úmido". ${ }^{13}$ Em 1663, outro visitante inglês, o marujo Edward Barlow, é ainda mais preciso: "No que se refere ao clima, o inverno daqui é o nosso verão. E mesmo durante esse inverno, excetuando os dias de chuva, o clima é mais quente do que aquele que temos durante o verão". ${ }^{14}$ Pouco depois dele, em 1666, um capuchinho italiano, Dionigi Carli, de passagem por Recife, a caminho do Congo, também não sentiu nada de ameno no clima:

Há somente duas estações neste país: uma primavera bastante temperada, mas muito chuvosa, durante a qual as árvores não perdem as suas folhas; e um verão muito quente e muito seco, de tal modo que, se não fosse o orvalho, a terra seria toda queimada e ressecada. ${ }^{15}$

Gradativa percepção da "realidade", isto é, de que o clima do país era tropical e de que nada tinha de ameno? Longe disso. Ao longo do século XVIII, independente das regiōes visitadas ou das estaçôes em que cada visita se deu, as opiniōes continuam a oscilar. É tal oscilação que permite ao inglês amante da história natural, James Forbes, passar pelo Brasil em pleno verão de 1765 e asseverar: “[...] a fertilidade dos vales, a suavidade do clima e a beleza da vida animal e vegetal conferem especial interesse a esta parte da América do Sul". ${ }^{16}$

Todavia, ao longo do século XVIII, malgrado a persistência da percepção do clima temperado e da reafirmação dessa ideia, o calor dos trópicos passa, num crescendo, a realmente tocar os visitantes estrangeiros e, sobretudo, a parecer-lhes bastante inóspito e insalubre. Logo no início do século, em 1703, um traficante de escravos anônimo que perambulara pela costa da África e da Bahia e encaminhava-se para o Rio da Prata, ao passar pelo porto carioca registrou:

Não obstante o sol estar a mais de $40^{\circ}$ de nós, o calor que se faz sentir é muito forte. Tive a impressão de que, na Bahia, o sol estava mais próximo umas duzentas léguas, mas o clima era mais ameno. A mesma coisa acontece frequentemente na Europa. O calor, às vezes, chega a ser maior em agosto do que em junho, apesar de o sol estar mais distante naquele mês. ${ }^{17}$

O sábio Frézier, que desconhecia o clima carioca, não ficou insensível ao calor baiano e, depois de uma estadia em Salvador, comentou: "aproveitei ao máximo o tempo livre para visitar a cidade e seus arredores, malgrado a chuva constante, intercalada com um calor insuportável”. Behrens, o alemão engajado na nau holandesa de Jacob Roggeveen, ressentiu-se igualmente do calor, não da Bahia, mas de São Sebastião, no litoral paulista, cujo clima, em novembro de 1723, suscitou o seguinte comentário seu: "o ar aqui é bem saudável, mas, em certas épocas do ano, faz um calor excessivo”. Um outro anônimo, um militar francês a caminho da costa do Coromandel, um quarto de século mais tarde, em 1748, mesmo pisando em solo carioca entre os meses de abril e maio, observou incomodado:

O calor é bastante forte. Durante os meses que passamos na cidade, apesar de ser inverno, enfrentamos dias mais quentes do que aqueles que temos no nosso verão. Esse calor excessivo poderia ter consequências funestas se não fosse amenizado por duas brisas: uma que sopra pela manhã, de noroeste, e outra que sopra à tarde, de sudeste. ${ }^{18}$

O "quase paraíso" de Vespúcio, no entanto, por sorte não era composto somente pelo clima, que de ameno e salubre no século XVI passou, no final do século XVIII, a merecer a reputação de excessivamente quente e, o que é pior, insalubre. O florentino também mencionara a exuberância da flora local, tema que cedo passou a marcar presença constante nos relatos sobre o Brasil e, ao contrário do clima, não sofreu qualquer variação ao longo de três séculos. As narrativas provenientes da França Antártica, mais uma vez, tiveram um papel importante na consolidação desta tópica. Recorramos novamente a Nicolas Barré. Depois de descrever para os seus leitores um grande número de produtos que havia encontrado na nova terra, empolgado, conclui o piloto:

A terra produz, ainda, favas grandes e pequenas, ambas muito boas para comer, e uma quantidade pouco significativa de cana-de-açúcar. Também em pequena quantidade são os limôes e laranjas aqui encontrados, 
pois os habitantes locais são extremamente negligentes no seu cultivo. Quanto às plantas medicinais, eu encontrei somente a beldroega, o mirto e o manjerico. Todo o resto é tão selvagem e grande que, se mestre Jean, o herbanário, aqui estivesse, ficaria, sem dúvida, bem embaraçado. ${ }^{19}$

Cerca de meio século mais tarde, na outra França, a Equinocial, Louis Pezieu, em coro com seus companheiros capuchinhos instalados no Maranhão - Claude D’Abbeville, Arsène de Paris, Yves D’Evreux -, fala numa "primavera eterna”. Dos piratas de Cavendish que visitaram Santos em 1591, o que melhor e mais pausadamente conheceu a terra, o prisioneiro Anthony Knivet, não deixou de mencionar no seu pormenorizado relato o quão ricas, verdejantes e variadas eram as matas locais, onde chegou a ver até mesmo "leopardos e leões". ${ }^{20}$

Depois do largo manancial de notícias editadas pelos holandeses, ${ }^{21}$ o pirata-escritor Dampier gastou nada menos do que cinco páginas, das poucas de seu relato dedicado a descrever sua passagem pela Bahia no ocaso do século XVII, comentando detalhadamente diferentes tipos de árvores que, segundo explica, "não são grandes, mas estão sempre verdes e florescentes". Um pouco mais tarde, em 1714, o misterioso comerciante Le Gentil La Barbinais, de passagem pela ilha Grande a caminho do Pacífico, discordou ligeiramente do renomado capitão Dampier, não no que tange ao verde eterno nas plantas e à variedade das árvores, mas no tocante ao seu tamanho - menores do que as da Europa, segundo dissera o capitão. Depois de perambular uma tarde pela ilha, contrariado, o francês comentou:

Tive a oportunidade de ver árvores de um tamanho que não supunha que a natureza fosse capaz de produzir. Meu mau humor, porém, fez com que murmurasse: a natureza parece uma mãe para estes bárbaros e trata-nos como uma madrasta. As laranjeiras e os limoeiros, árvores tão preciosas, nascem nesta ilha e em toda a América sem nenhuma cultura, e nascem para fazer sombra para os macacos e crocodilos.

Tão impressionante para os visitantes quanto a exuberância da vegetação local - cuja variedade e singularidade levou o aventureiro Flecknoe a afirmar que "nem uma só árvore ou planta [...] apresentava semelhança com as da Europa"22 - era a diversidade da fauna, a terceira das quatro tópicas vistas e revistas desde Vespúcio. A variedade dos pássaros, por exemplo. Raro o visitante que deixou de se referir, com mais ou menos detalhes, às vistosas e coloridas aves do Brasil - país conhecido, desde 1501, isto é, desde a suposta edição da carta de Giovanni Cretico, como "Terra dos Papagaios". ${ }^{23}$ O mencionado aventureiro Flecknoe, por exemplo, legou-nos a esse respeito um comentário lapidar. Depois de alguns passeios pelos arredores do Rio de Janeiro, o poeta inglês sentenciou:

As aves são tão belas que poderíamos afirmar que a natureza aprendeu aqui os seus matizes antes de pintar as nossas. Conquanto os pássaros da Arábia sejam chamados aves do Paraíso, merece o Brasil o nome de Paraíso das aves. ${ }^{24}$

Passam-se os anos e o fascínio permanece. Em 1768, o renomado capitão Cook, malgrado a desagradável recepção que teve no Rio de Janeiro - o capitão foi muitíssimo mal recebido pelo então vicerei Conde de Azambuja -, não deixou de manifestar o quanto lhe agradara a flora e a fauna local, especialmente as aves:

As imediações da cidade que tivemos oportunidade de conhecer são muito agradáveis. Os lugares mais selvagens são cobertos por uma grande quantidade de flores, que, no tocante ao número e à beleza, superam aquelas dos jardins mais elegantes da Inglaterra. Sobre as árvores e arbustos, é possível encontrar uma quantidade infinita de pássaros, a maior parte deles coberta com plumagem brilhante. O que mais chamou a nossa atenção foi o colibri. ${ }^{25}$

As verdes e impenetráveis florestas brasileiras, construídas nas páginas das narrativas de viagem, não eram, contudo, habitadas somente por uma variedade infinita de pássaros. O imaginativo Thévet, por exemplo, além de um capítulo dedicado às aves, Das aves mais comuns da América, não deixou de dedicar umas poucas páginas de seu relato a descrever uma série de animais que eram caçados e consumidos pelos 
nativos, todos diferentes daqueles da Europa. Um dos seus colegas de aventura, o piloto Nicola Barré, passou ao largo tanto dos animais quanto dos pássaros, o mesmo não ocorrendo com Léry que, não somente dedicou especial atenção às aves - "tão diversas das nossas nas cores que lhe são peculiares" ${ }^{6}$-, como ainda detalhou para seus leitores os peixes e os animais mais comuns na região da baía de Guanabara.

Staden também dedicou umas tantas páginas de sua narrativa aos animais da nova terra, aos que viu e aos que supôs existir em matas tão amplas e densas: veados, porcos do mato, tatus, tigres, leóes, capivaras e uns tantos outros. Knivet, o companheiro de Cavendish abandonado em São Sebastião, malgrado ter vivido no país por meses, não é pródigo no que tange à descrição dos animais da terra, salvo de uma espécie de monstro marinho que diz ter visto nas proximidades do Rio de Janeiro. Muito mais atenção aos peculiares bichos que habitavam o mundo novo deram, nas primeiras décadas do século XVII, os capuchinhos envolvidos na segunda malsucedida tentativa francesa de se instalar na América Austral: a França Equinocial. Abbeville, por exemplo, dedicou um capítulo aos pássaros - "é impossível dizer quantas espécies de pássaros se encontram na ilha do Maranhão e circunvizinhanças, muito diferentes todos dos nossos" 27 , outro aos peixes, outro aos insetos (os "animais imperfeitos") e um aos "animais terrestres”, no qual, do tamanduá à preguiça, descreve pacientemente a longa série de bichos - exóticos uns, ligeiramente familiares outros - que encontrou nos seus quatro meses de estadia no Maranhão. ${ }^{28}$

Pezieu não vai tão longe, pois suas sintéticas cartas não comportavam tamanha dose de minúcias. Malgrado tal limitação, o companheiro de Abeville, visivelmente seduzido pelas riquezas naturais do Maranhão e muitíssimo interessado em convencer os seus conterrâneos do quão importante era manter a presença francesa no lugar - "a porta de entrada para territórios com riquezas infinitas", como explicou aos seus companheiros -, registrou em uma de suas cartas:

As matas estão cheias de cervos, corças, macacos - muito melhores do que os da França - e de diversos outros animais que não temos, com aparência totalmente distinta dos animais da Europa e com o sabor melhor do que o das lebres, dos lebrachos, dos láparos e de outros.

Pouco antes dos franceses, em 1601, William Davies, um inglês que veio parar, na qualidade de escravo de um navio italiano, na embocadura do rio Amazonas, também não deixara de comentar, na sua brevíssima narrativa, o quão variada era a fauna local:

Permaneci dez semanas no Amazonas e pude observar o modo de ser do povo e as características do lugar. A região é inteiramente coberta por florestas e povoada por todo tipo de animais selvagens, tais como leões, ursos, lobos, leopardos, babuínos, saguis, javalis esquisitos, macacos, andorinhōes e muitos outros bichos estranhos. Os bosques estão cheios de pássaros selvagens dos mais variados e é possível encontrar mais papagaios por aqui do que pombos na Inglaterra - a propósito dos papagaios, cheguei a comer vários deles e devo dizer que são muito saborosos.

Laval, o aventureiro que legou à França a primeira descrição da ilha de Madagascar, não visitou nenhuma região selvagem - o francês conheceu somente Salvador -, mas não deixou de registrar o que ouvira falar sobre as matas próximas à cidade:

A caça é muito pouco praticada, pois a região tem uma mata muito densa e está repleta de animais ferozes, o que faz com que os brasileiros não ousem entrar nos bosques com medo de serem devorados.

O marinheiro inglês Edward Barlow, na sua passagem pelo Rio de Janeiro, não desceu a minúcias, no entanto, atento às expectativas que os leitores europeus já haviam formado no que tange a descriçôes do Brasil, registrou:

As redondezas da cidade são cobertas por florestas e cortadas por riachos, daí a presença de muitos animais selvagens, como os leopardos e os tigres, e de uma infinidade de pássaros, como os papagaios, os periquitos e as araras. ${ }^{29}$ 
O mesmo tom protocolar, isto é, o tom de quem põe em cena objetos e situações que sabe serem ansiosamente aguardados por seus prováveis leitores, encontramos na narrativa publicada por Souchu de Rennefort, dando conta da passagem do senhor de Mondevergue por Pernambuco, em 1666. Diz o visitante: "Abundam no país os avestruzes e os papagaios de bela plumagem; encontram-se, também, pelas matas, muito gado selvagem, tigres, onças e quatis, estes bem menores e bem menos agressivos do que os tigres". Froger, três décadas mais tarde, formulará sentença quase idêntica acerca dos arredores de Salvador: "Há uma quantidade extraordinária de aves e os mais belos papagaios do mundo; em relação à caça, há tigres, cervos, javalis e uma série de outros animais desconhecidos na Europa". Dampier, em 1699, sobre os mesmos arredores de Salvador, é ligeiramente mais detalhista, mas o tom é o mesmo:

Os tigres e leopardos do país têm a reputação de serem grandes e ferozes. Aqui na costa, porém, já foram completamente exterminados ou expulsos para o interior. É, pois, muito raro encontrá-los aqui, salvo nos limites das plantaçōes, onde por vezes vêm caçar.

Há, na Bahia, três ou quatro tipos de macacos, de diferentes tamanhos e cores. Um dos tipos é enorme e o outro minúsculo; este tem a forma e a feição horrorosos e um forte cheiro de almíscar.

Serpentes de diversos tipos abundam na região, muitas delas enormes e a maioria muito venenosa.

Enfim, para encerrarmos essa já longa série, recorramos a um visitante de 1745 que passou pelo sul do Brasil, nomeadamente pela ilha de Santa Catarina, o abade René Courte de La Blanchardière. Mudam-se os tempos e as latitudes, mas o tom e as imagens são os mesmos:

As terras ao redor são bastante elevadas e de tal modo cobertas pela vegetação que se tornam incultiváveis; há, contudo, algumas faixas de terra nas quais os índios têm trabalhado. As matas estão repletas de tigres, macacos, javalis, papagaios e diversos outros animais.

Nada, todavia, em se tratando da natureza dos trópicos, mereceu mais atenção do visitante do que a prodigalidade da terra, o quarto dos componentes centrais da modelar descrição de Vespúcio. É raro encontrar um relato acerca do Brasil em que não haja ao menos uma pequena referência ao quão fértil era o solo local. Recorramos mais uma vez ao poeta Flecknoe:

A terra é quase toda coberta de matas e, com o solo virgem desde a criação do mundo, produz, sem nenhuma cultura, árvores frondosas e enormes, algumas das quais com sete ou oito braças de diâmetro e mais de 70 ou 80 de altura. ${ }^{30}$

Antes dele, de Vespúcio aos holandeses instalados no Nordeste, passando pelos franceses das Franças Antártica e Equinocial, por Hans Staden, Anthony Knivet, Pierre Laval e tantos outros, todos invariavelmente abraçaram a ideia do "em se plantando tudo dá", e dá até mesmo sem plantar, sem nenhuma cultura, como se costumava dizer na época. Yves d'Evreux, líder dos capuchinhos da França Equinocial, que durante dois anos permanecera no Maranhão - e não por quatro meses, como salienta o próprio Evreux, referindo-se a Abeville -, legou-nos uma lapidar passagem sobre o tema:

A terra é vigorosa, fértil e muito [...] estável para o plantio. Disseram-me que se poderia obter aí duas colheitas anuais. As árvores da região são de tamanho avantajado, estão sempre verdes até o topo e contam com madeiras excelentes, seja pela cor, seja pelas suas propriedades medicinais.

Depois dele e da ocupação holandesa, o senhor de Mondevergue, o primeiro estrangeiro a descrever Pernambuco após a expulsão dos batavos, antes de explicar aos seus leitores a enorme variedade de frutas que encontrou em Recife e em Olinda quando de sua visita em 1666, sentenciou: "toda a terra do Brasil é boa, mas mal cultivada". Um século mais tarde, Jemima Kindersley, a inglesa que visitou Salvador em 1764, lapidou este raciocínio:

Há, espalhadas pela região, umas poucas propriedades rurais, com jardins providos com toda variedade de frutas, como bananas, melōes, tamarindos, limas, cidras, limões, limões doces, romãs, melancias, e com ár- 
vores enormes cujos galhos vergavam sob o peso das laranjas - fruta que aqui é extremamente comum e muitíssimo saborosa. Há uma espécie em particular, quatro vezes maior do que aquelas que recebemos da Espanha e de Portugal e sem sementes, que tem um sabor maravilhoso.

O trabalho do agricultor é pouquíssimo requisitado por aqui, na medida em que, com um clima e um solo como estes, os mais variados frutos da terra crescem quase espontaneamente. ${ }^{31}$

Creio que temos, nestas poucas páginas, um quadro razoável do cenário natural do Brasil construído pelos visitantes estrangeiros. Vespúcio, sem dúvida, deu o tom, ao atribuir à terra características de um "quase paraíso", isto é, ao atribuir à terra características extraídas de uma certa ideia de paraíso presente na cultura Ocidental, características tais como: a agradabilidade do clima - nem quente nem frio -, o verde eterno e a exuberância das matas, a variedade da fauna - dos pássaros, sobretudo - e a desmedida fertilidade da terra, que quase dispensava o labor humano para prodigalizar seus frutos. Uma "visão do paraíso"? Repito: nem tanto, na verdade, melhor seria falarmos numa "terra rica e aprazível", uma terra com bom clima, bons rios, bons portos etc., cuja fertilidade anunciava muitas riquezas aos seus colonizadores. O uso da metáfora do paraíso, é bom reafirmar, ao contrário do que por vezes se apregoa, não ganhou muitos adeptos e cedo perdeu a sua força e a sua presença nas xenorrativas de viagem com mençôes ao Brasil. ${ }^{32}$

Mas caminhemos adiante, entremos na construção da imagem do mundo que o português estava criando nos trópicos e no outro tema que aqui interessa em particular, a vida erótica local. A constatação da enorme prodigalidade da terra do Brasil vem, como vimos, quase sempre acompanhada de cortantes observaçóes sobre o quão sem cultivo era essa mesma terra e o quanto as poucas culturas existentes eram mal cuidadas. Daí passa-se, inevitavelmente, a uma apreciação da qualidade dos colonos, apreciação, na quase totalidade dos casos, bastante negativa.

Indolente, cruel, arrogante, vaidoso, ignorante, ciumento, luxurioso, são alguns dos muitos qualificativos utilizados pelos viajantes estrangeiros para descrever os portugueses aclimatados nos trópicos os elogios são exíguos. Acompanhemos com mais vagar como dois deles, ciumento e luxurioso, foram construídos nas xenonarrativas. A reputação de que os portugueses dos trópicos eram destemperados em matéria de amor e capazes de atos tresloucados em seu nome estava tão consolidada na Europa que o explorador inglês James Tuckey, em 1807, otimista com as mudanças pelas quais supunha passarem os hábitos e os costumes dos cariocas, asseverou:

Viajantes anteriores sempre lamentaram a dificuldade que encontravam para pôr os olhos sobre uma brasileira decente. Tal situação, no entanto, alterou-se muito. Hoje, a bem da verdade, as maneiras das mulheres do Rio de Janeiro, das solteiras especialmente, aproximam-se muito mais da informalidade das inglesas do que da pudica reserva que, dizem, caracteriza as portuguesas. E como melhoraram os costumes do povo em geral, o ciúme de outrora vem dando lugar a uma gentil atenção para com o sexo oposto. Os homens começam a depositar confiança nas mulheres, as quais, mais conscientes do seu próprio valor, rapidamente estão adquirindo aquele amor próprio que sustenta a virtude feminina. ${ }^{33}$

Muitos tinham sido realmente os "viajantes anteriores" que lamentaram a impossibilidade de contatar as mulheres brasileiras, tamanho era o ciúme do sexo oposto, um ciúme que, segundo eles, não raro ocasionava crimes de sangue. Corria, inclusive, entre os navegadores, a história de que um capelão da embarcação que acompanhava o navio do renomado Louis Antoine Bougainville, ao passar pela cidade do Rio de Janeiro em 1768, se metera numa querela amorosa e acabara assassinado. Entre os europeus, o caso - o que não é de se espantar - tomou ares de verdade, na medida em que a opinião corrente era, com mais ou menos floreios, a expressa pelo cirurgião inglês George Hamilton em 1790:

Aqui, os estiletes são muito utilizados, os assassinatos são frequentes, os homens são possuídos por um ciúme sanguinário e as mulheres, que nunca aparecem em público sem a proteção de um véu, são muito dadas à galanteria. ${ }^{34}$ 
A propósito do comentário de Hamilton, se tomarmos ao pé da letra o que insinua o cirurgião inglês e uma centena de outros visitantes, os colonos tinham razão de sobra para desconfiar de suas parceiras e estas deles, pois, como então se dizia, ninguém na terra primava pelo recato. Talvez o grande propagador na Europa dessa péssima imagem do brasileiro, da brasileira sobretudo, tenha sido o capitão James Cook. De passagem pelo Rio de Janeiro em 1768, o renomado capitão (protagonista de três viagens de circunavegação) fez uma série de considerações sobre os cariocas, que acabaram por virar cantilena entre os viajantes que o sucederam. Eis o que diz Cook:

Creio que todos estarão de acordo em admitir que as mulheres das colônias espanholas e portuguesas da América meridional concedem seus favores mais facilmente do que aquelas dos países civilizados. No que se refere ao Rio de Janeiro, algumas pessoas chegam a afirmar que na cidade não há uma única mulher honesta. Essa condenação é seguramente muito generalizante. O Dr. Solander, todavia, durante sua permanência na cidade, não foi capaz de elogiar a castidade dessas senhoras. Disse-me ele que, ao cair da noite, elas apareciam nas janelas, só ou acompanhadas, e jogavam buquês de flores sobre os seus eleitos quando esses passavam pela rua. Ainda segundo o doutor, ele e mais dois ingleses que o acompanhavam receberam um número tal de distinçôes que, ao final de um curto passeio, os seus chapéus estavam cobertos de flores. ${ }^{35}$

É verdade que, antes do capitão, outros viajantes já haviam feito insinuaçôes sobre o gosto exacerbado dos brasileiros e brasileiras pelos prazeres da carne. É sempre temerário demarcar um momento inaugural nestes domínios, mas creio que a conduta sexual do colono ${ }^{36}$ estreia na literatura de viagem em 1610, e da pior maneira. A mulher brasileira de moralidade pouco rígida, sempre disposta a realizar os mais secretos desejos do visitante apressado aparece, então, nas páginas de um relato que se tornaria bastante conhecido na época, intitulado Viagem de François Pyrard de Laval. O livro de Laval, um navegador francês que aportou na cidade de São Salvador em maio de 1610, ao retornar das Índias Orientais, traz uma história curiosa, que se tornou tão conhecida na Europa a ponto de reaparecer, com ligeiras alteraçôes (a aventura agora se passa em Santos), no relato de um tal Francisco Coreal, aventureiro espanhol que supostamente - há muitas dúvidas sobre a autenticidade de sua narrativa - teria passado pelo Brasil em 1685.

Relata-nos Pyrard que, certo dia, andava pelas ruas da cidade de Salvador, quando subitamente se viu abordado por "rapariga negra de Angola" que, sem qualquer cerimônia, o tomou pela mão e o levou até a casa de uma jovem dama portuguesa. Gaba-se o francês de que essa dama prestou-lhe, ao longo de muitas visitas, "uma infinidade de obséquios e favores", favores que, concluía o visitante, não raro eram obtidos pelos europeus que visitavam o lugar, pois as damas locais eram "afáveis e muito amigas dos estrangeiros".

A linhagem inaugurada por Laval cedo teve seguidores. Em 1676, Gabriel Dellon - um cirurgião condenado pelo Tribunal da Inquisição de Goa -, a caminho de Lisboa para cumprir sua pena, desembarcou em Salvador e, depois de pouco mais de um mês de permanência entre os baianos, descreveu-os, mulheres e homens, brancos, negros e mulatos, como "mergulhados na libertinagem"; e mais, salientava Dellon: tinha ouvido dizer que os baianos eram pudicos, se comparados aos brasileiros de outras regiōes.

Ainda no século XVII, um século relativamente pobre em narrativas de estrangeiros sobre o Brasil, William Dampier, em 1699, insinuou, no seu conhecido e muito reeditado Viagem à Nova Holanda, que as baianas tinham um especial apreço pelos estrangeiros. Ponderou, contudo, que era bastante arriscado corresponder a tal estima, pois os baianos, extremamente ciumentos, mas igualmente libertinos, não hesitavam em matar ou em mandar matar um galanteador mais ousado.

É, no entanto, ao longo do século XVIII que vêm a público aquelas narrativas que, mais detalhadas, acabarão por realmente consolidar como um "lugar-comum” a sugestão de Laval sobre a vida erótica local. Logo no início do século, em 1713, o sábio Amédée Frézier, ao retornar de sua viagem ao Mar do Sul, passou pela Bahia e não deixou de observar, como Dampier, que os homens eram ciumentos e não poupavam cuidados no sentido de proteger a moral de suas filhas e esposas. Apesar de tais cuidados, porém, prossegue Frézier, as mulheres eram todas "libertinas" e a amoralidade atingia um ponto tal que, em casos extremos, as próprias mães acobertavam e mesmo auxiliavam os atos impuros das filhas. 
Outro francês, Le Gentil La Barbinais, também de passagem pela Bahia, foi um pouco mais longe nas suas observações. Barbinais notou também que as mulheres brancas eram "todas dissolutas", mas deulhes certa razão para adotarem tal comportamento, pois constatou que os colonos brancos, volta e meia, trocavam-nas pelas negras da Guiné ou pelas muitíssimo apreciadas mulatas.

A conduta moral do brasileiro não foi elogiada nem mesmo pela única mulher europeia a deixar registradas as suas impressões sobre o Brasil colonial: a inglesa Jemima Kindersley. A senhora Kindersley, em uma de suas missivas, datada de 1764, deixou registrado o seguinte:

Depois do que afirmei sobre o caráter geral dos homens deste lugar, não espere ouvir nada de muito elogioso sobre as mulheres. Acostumadas à indolência e incultas, a sua vivacidade natural manifesta-se na astúcia. Os homens de sua relação não depositam lá muita confiança nas suas virtudes, elas, por sua vez, usam toda a sua esperteza para iludir a vigilância a que estão submetidas. E, a bem da verdade, elas são, para dizer o mínimo, bastante inclinadas às intrigas amorosas. Pudera eu contar-lhe o que a escuridão da noite oculta daquelas que, durante o dia, são vistas somente nas igrejas, e as minhas missivas pareceriam um libelo sobre o sexo.

Vê-se, pois, que os visitantes europeus não julgavam de todo despropositado o ciúme dos brasileiros, na medida em que, segundo esses mesmos visitantes, ninguém nessas plagas era lá muito casto. Ao menos é o que se conclui da conversação que o médico John Barrow travou, em 1792, com um religioso estabelecido na então capital da colônia. Ouçamo-lo:

A abadessa de um convento próximo da nossa residência queixou-se, um dia, ao doutor de que sofria de fortes dores de cabeça e pediu-lhe algumas pílulas. Por causa dos preparativos da nossa partida, o doutor colocou as tais pílulas numa caixa e solicitou a um alegre monge da Ordem de São Benedito que a entregasse, o mais rápido possível, à abadessa. A extrema curiosidade do noviço levou-o a abrir a encomenda. Depois de examinar o seu conteúdo e lançar um significativo olhar para o doutor, o religioso fez o seguinte comentário: Aha Domine, mercurialia! Ista sunt mercurialia! Diante do ar descontente e aborrecido do doutor, desgostoso com a insinuação acerca do possível mal que afligia a abadessa, o monge, soltando uma gargalhada, exclamou: a senhora abadessa e todas as damas do Rio de Janeiro pronae sunt omnes ac deditae veneri. Por fim, ele contou-nos abertamente que a maior parte das mulheres sofria as consequências nefastas do seu comércio com os estrangeiros. Suas insinuações maldosas estenderam-se também aos homens, insinuações que, verdadeiras ou não, eram tão indecentes quanto o caráter daquele que as fazia.

Despropositado ou não, o certo é que os rótulos de ciumento e libertino, ou melhor, de perigosamente ciumento e excessivamente libertino agregaram-se de vez ao rol dos muitos defeitos dos portugueses da América, agregaram-se de vez àquele rol que incluía ainda a crueldade, o pouco apreço pelas atividades produtivas, a desonestidade, a vaidade excessiva e uns tantos atributos negativos.

Não é necessário ir mais além para concluir o quão ruim era a imagem desses homens e mulheres para os visitantes europeus. Poderíamos mesmo dizer que os habitantes da América portuguesa descritos nos relatos de viagem têm tantos defeitos quantas são as qualidades apontadas na natureza dos trópicos, e um dentre tais defeitos, talvez o mais saliente, era a libertinagem. Uma excelente síntese de tão notório raciocínio é-nos dada, em 1748, por um oficial anônimo da marinha francesa. Diz o marinheiro:

A cada dia que passa, o sangue mistura-se mais e mais, pois o clima e a ociosidade tornam o povo fortemente inclinado à libertinagem. A ociosidade, a propósito, passa, entre eles, por sinal de dignidade, pois jamais pensam no bem comum, agindo somente em proveito próprio. E isso num país que oferece tudo sem muito esforço.

Eis um esboço do mundo natural e da conduta erótica dos colonos construídos nas páginas dos relatos de viagem dos séculos XVI, XVII e XVIII, um esboço que, não obstante a sua imprecisão e precariedade, dá-nos uma ideia razoável da imagem que tinham os europeus do mundo que os portugueses estavam construindo nos trópicos para usarmos a expressão celebrizada por Gilberto Freyre.

Para concluir, gostaria somente de tecer duas ou três consideraçôes sobre os usos que pode ter hoje o esquadrinhamento e a análise dessa faceta dos habitantes do Brasil colonial construída nas narrativas 
de viagem europeias dos séculos XVI, XVII e XVIII. É certo que, uma vez submetidos a um exame crítico e confrontados com outras fontes coetâneas, esses textos podem ser utilizados como "documentos", isto é, como "perspectivas", pontos de vista, mais ou menos verossimilhantes, acerca do mundo natural e, sobretudo, acerca das "inclinações morais" da sociedade colonial - é óbvio que se trata de um discurso socialmente determinado, com todas as implicaçóes que isso acarreta, o eurocentrismo inclusive. Tais escritos podem, igualmente, se precedidos de uma análise mais pormenorizada do lugar que produtores e produtos ocuparam na sociedade europeia de então, propiciar um melhor entendimento do alcance que a descoberta e a exploração do Novo Mundo tiveram no Velho Mundo e das características que o europeu atribuiu aos habitantes da América, características que irão, em larga medida, condicionar as ações dos europeus em relação aos homens e às coisas do continente. Foi esse mapeamento que se tentou timidamente realizar neste pequeno ensaio.

A esses usos acrescentaria um último, estreitamente relacionado com a história da formação da cultura e do povo brasileiros. Refiro-me ao estudo da influência que a imagem do Brasil, elaborada pelos visitantes do Velho Mundo, a erótica sobretudo, teve sobre a elite imperial brasileira da primeira metade do século XIX - a responsável pela implantação das bases da cultura que, depois de 1808, gradativamente, passou a se autodenominar nacional -, uma elite medicalizada e ansiosa por parecer, aos seus próprios olhos e aos olhos do europeu, mais “civilizada”. Ora, é sabido que uma parcela significativa dos homens que a compunham não somente obtiveram a sua formação cultural na Europa, como ainda sofreram uma influência sobremodo importante de muitos dos europeus (Debret, Denis, Spix e Martius, Rugendas, entre outros) que visitaram o Brasil na sequência da abertura dos portos. É lógico supor que esses novos visitantes trouxeram consigo muitas daquelas noções veiculadas pelas narrativas dos visitantes que os antecederam, as mesmas noçōes que boa parte da elite brasileira vinha aprendendo nos compêndios de além-mar que lia e nas escolas que frequentava, deste e do outro lado do Atlântico. É igualmente lógico cogitar que tais noçôes se incorporaram ao discurso sobre o país elaborado por essa elite e que algumas delas - como a "sexualidade à flor da pele", por exemplo - ganharam foros de nacionalidade, entrando, para bem e para mal, na composição da imagem que os brasileiros construíram de si próprios e do seu país. Mapeá-las é, pois, de certo modo, conhecer um pouco os contornos que atribuímos a nós próprios.

\section{Notas}

${ }^{1}$ ARCINIEGAS, Germán. América en Europa. Bogotá, Colombia: Plaza \& Janes, 1980, p. 129-154.

${ }^{2}$ A polêmica tese de que a América era um continente inferior foi minuciosamente analisada no já clássico livro de GERDI, Antonello. La disputa del Nuevo Mundo. Historia de una polémica (1750-1900). México: Fondo de Cultura Económica, 1993. O mesmo tema mereceu atenção de Arciniegas, no já citado América en Europa, p. 155-182.

${ }^{3}$ CHATEAUBRIAND, François-René. Atala. Texto fixado e apresentado por Gilbert Chinard. Paris: F. Roches, 1930.

${ }^{4}$ ZAVALA, Silvio. América en el espiritu francés del siglo XVIII. México: Colégio Nacional, 1949, p. 33-90.

${ }^{5}$ Não esqueçamos das vigorosas e concorrentes ondas de interesse pela Índia e pela China, nos séculos XVI e XVII, e, mais tarde, no século XVIII, pelo continente Austral.

${ }^{6}$ Lembremos que, em 1591, uma década depois da união dos tronos de Portugal e Espanha, foi proibida a vinda de navios estrangeiros para a América Portuguesa (9 de fevereiro) e que, em 1605, se interditou de uma vez por todas a presença deles na colônia e se estipulou o prazo de 12 meses para que os já residentes saíssem (18 de março). Tais restrições, ainda que não tenham sido respeitadas à risca, dificultaram as visitas de estrangeiros ao país.

${ }^{7}$ Pouco mais de uma centena.

${ }^{8}$ VESPÚCIO, Américo. Novo Mundo - As cartas que batizaram a América. São Paulo: Planeta do Brasil, 2003, p. 45.

${ }^{9}$ Ibid., p. 45-47.

${ }^{10}$ FRANÇA, Jean Marcel Carvalho. Outras Visões do Rio de Janeiro Colonial. Rio de Janeiro: José Olympio Editora, 2000, p. 333.

${ }^{11}$ LÉRY, Jean de. Viagem à terra do Brasil. Belo Horizonte: Ed. Itatiaia; São Paulo: Ed. da Universidade de São Paulo, 1980, p. 111. 
${ }^{12}$ STADEN, Hans. Duas viagens ao Brasil. Belo Horizonte, São Paulo: Itatiaia, Ed. da Universidade de São Paulo, 1974 , p. 152.

${ }^{13}$ FRANÇA, Jean Marcel Carvalho. Visóes do Rio de Janeiro Colonial. Rio de Janeiro: EdUERJ; José Olympio, 1999 , p. 36.

${ }^{14}$ Id. Ibid., p. 47.

${ }^{15}$ As citações de viajantes que não estiverem acompanhadas de notas são traduções extraídas da obra: FRANÇA, Jean Marcel Carvalho. A Construção do Brasil na Literatura de Viagem dos séculos XVI, XVII E XVIII. Rio de Janeiro: José Olympio. (no prelo). Informações sobre os viajantes citados podem ser encontradas em FRANÇA, Jean Marcel Carvalho; RAMINELLI, Ronald. Andanças pelo Brasil. São Paulo: Ed. Unesp, 2009.

${ }^{16}$ Visóes do Rio de Janeiro Colonial, p. 114.

${ }^{17}$ Id., Ibid., p. 58.

${ }^{18}$ Id. Outras Visóes do Rio de Janeiro Colonial, p. 219.

${ }^{19}$ Id. Visões do Rio de Janeiro Colonial, p. 21.

${ }^{20}$ KNIVET, Anthony. Vária fortuna e estranhos fados de Anthony Knivet, que foi com Tomás Cavendish, em sua segunda viagem, para o Mar do Sul, no ano de 1591. São Paulo: Brasiliense, 1947, p. 55.

${ }^{21}$ Os holandeses, a começar por um dos pioneiros no que tange a livros sobre o Brasil, Dierick Ruiters, também exaltaram a exuberância da vegetação local. Lembremos que saiu da pena de holandeses instalados em Pernambuco, durante o governo de Maurício de Nassau, a renomada Historia Naturalis Brasiliae, o mais completo e detalhado mapeamento da flora brasileira publicado durante o século e meio que antecedeu as obras dos naturalistas e sábios que deram nos portos brasileiros depois da abertura promovida por D. João VI.

22 FRANÇA, Jean Marcel Carvalho. Visóes do Rio de Janeiro Colonial, p. 36.

${ }^{23}$ AMADO, Janaína; FIGUEIREDO, Luiz Carlos. Brasil 500. Quarenta documentos. Brasília: Editora da Universidade de Brasília; São Paulo: Imprensa Oficial do Estado, 2001, p. 177.

${ }^{24}$ FRANÇA, Jean Marcel Carvalho. Visóes do Rio de Janeiro Colonial, p. 38-39.

${ }^{25}$ Ibid., p. 135.

${ }^{26}$ LÉRY, Jean de. Viagem à terra do Brasil, p. 153.

${ }^{27}$ ABBEVILLE, Claude d'. História da missão dos padres capuchinhos na ilha do Maranhão. Apres. de Mário Guimarães Ferri. Belo Horizonte: Ed. Itatiaia; São Paulo: Ed. da Universidade de São Paulo, 1975, p. 182.

${ }^{28}$ D'ÉVREUX, Père Yves. Voyage dans le nord du Brésil fait durant les années 1613 et 1614. Avec une introduction et des notes par M. Ferdinand Denis. Leipzig, Paris: Libraire A. Franck, 1864, p. 147-208.

${ }^{29}$ FRANÇA, Jean Marcel Carvalho. Visões do Rio de Janeiro Colonial, p. 47.

${ }^{30}$ Ibid., p. 36.

${ }^{31}$ Jemima Kindersley. In: FRANÇA, Jean Marcel de Carvalho. Mulheres viajantes no Brasil (1773-1820). Rio de Janeiro: José Olympio, 2007, p. 31.

${ }^{32}$ Referimo-nos, aqui, nomeadamente, ao conceituado trabalho de Sérgio Buarque de Holanda, Visão do Paraíso. Há de se ter em conta, contudo, que a presença minguada da ideia de paraíso nas narrativas de viagem, escritas por estrangeiros, não é extensiva aos escritos sobre o Brasil produzidos por brasileiros ou lusitanos, escritos de circulação restrita, que contaram com tiragens pequenas, não ganharam nenhuma tradução e, não raro, foram vítimas da censura portuguesa, como, por exemplo, o Notícias curiosas e necessárias das cousas do Brasil (1668), do padre Simão de Vasconcelos, onde se encontram sete parágrafos - banidos na primeira edição da obra - em que o autor defende, sustentado nos doutores da igreja, que o Brasil poderia ser o "paraíso na terra". VASCONCELOS, Simão. Notícias curiosas e necessárias das cousas do Brasil. Introd. e recolha de textos por Luís A. de Oliveira Ramos. Lisboa: C.N.C.D.P., 2001, p. 161-164.

${ }^{33}$ FRANÇA, Jean Marcel Carvalho. Outras Visöes do Rio de Janeiro Colonial, p. 267.

${ }^{34}$ Ibid., p. 242.

${ }^{35}$ Id. Visóes do Rio de Janeiro Colonial, p. 134.

${ }^{36} \mathrm{O}$ índios amantes da concupiscência apareceram nas páginas da literatura de viagens bem mais cedo, em 1506, nas conhecidas cartas de Américo Vespúcio.

\section{Referências bibliográficas}

ABBEVILLE, Claude d'. História da missão dos padres capuchinhos na ilha do Maranhão. Apres. de Mário Guimarães Ferri. Belo Horizonte: Ed. Itatiaia; São Paulo: Ed. da Universidade de São Paulo, 1975.

AMADO, Janaína; FIGUEIREDO, Luiz Carlos. Brasil 500. Quarenta documentos. Brasília: Editora da Universidade de Brasília; São Paulo: Imprensa Oficial do Estado, 2001. 
ARCINIEGAS, Germán. América en Europa. Bogotá, Colombia: Plaza \& Janes, 1980.

CHATEAUBRIAND, François-René. Atala. Texto fixado e apresentado por Gilbert Chinard. Paris: F. Roches, 1930.

D’ÉVREUX, Père Yves. Voyage dans le nord du Brésil fait durant les années 1613 et 1614. Avec une introduction et des notes par M. Ferdinand Denis. Leipzig, Paris: Libraire A. Franck, 1864.

FRANÇA, Jean Marcel Carvalho. A Construção do Brasil na Literatura de Viagem dos séculos XVI, XVII e XVIII. Rio de Janeiro: José Olympio. (no prelo).

. Outras Visões do Rio de Janeiro Colonial. Antologia de Textos (1582-1808). Rio de Janeiro: José Olympio Editora, 2000. pio, 1999.

. Visôes do Rio de Janeiro Colonial. Antologia de Textos (1531-1800). Rio de Janeiro: EdUERJ; José Olym. Mulheres viajantes no Brasil (1773-1820). Rio de Janeiro: José Olympio, 2007.

\& RAMINELLI, Ronald. Andanças pelo Brasil. São Paulo: Ed. Unesp, 2009.

GERDI, Antonello. La disputa del Nuevo Mundo. Historia de una polémica (1750-1900). México: Fondo de Cultura Económica, 1993.

KNIVET, Anthony. Vária fortuna e estranhos fados de Anthony Knivet, que foi com Tomás Cavendish, em sua segunda viagem, para o Mar do Sul, no ano de 1591. São Paulo: Brasiliense, 1947.

LÉRY, Jean de. Viagem à terra do Brasil. Belo Horizonte: Ed. Itatiaia; São Paulo: Ed. da Universidade de São Paulo, 1980.

STADEN, Hans. Duas viagens ao Brasil. Belo Horizonte, São Paulo: Itatiaia, Ed. da Universidade de São Paulo, 1974 .

VASCONCELOS, Simão. Notícias curiosas e necessárias das cousas do Brasil. Introd. e recolha de textos por Luís A. de Oliveira Ramos. Lisboa: C.N.C.D.P., 2001.

VESPÚCIO, Américo. Novo Mundo - As cartas que batizaram a América. São Paulo: Planeta do Brasil, 2003.

ZAVALA, Silvio. América en el espiritu francés del siglo XVIII. México: Colégio Nacional, 1949.

\section{RESUMO}

O ensaio aborda a literatura de viagem sobre o Brasil, escrita ao longo dos séculos XVI, XVII e XVIII, com o intuito de extrair dai uma pequena amostra da imagem que o europeu construiu do mundo natural e de um dos aspectos da conduta moral das gentes dos trópicos portugueses, aquele ligado à vida erótica do brasileiro, à sua relação com os prazeres da carne. Trata, pois, de uma tentativa muita limitada de mapear uma pequena parte das verdades sobre o Brasil e suas gentes que o europeu construiu e partilhou ao longo dos séculos, verdades que, em larga medida, guiaram as suas açôes nesta parte do globo.

Palavras-chave: hábitos coloniais, literatura de viagem, viajantes, erotismo colonial, perspectivas da natureza tropical.

\section{ABSTRACT}

This essay focuses on travel literature about Brazil, written during the sixteenth, seventeenth and eighteenth centuries, with the intention of drawing from this small sample, an image that was built of nature and the moral conduct of the people in the tropics - specially the erotic life of Brazilians and its relationship with the pleasures of the flesh. It is therefore a very limited attempt to map a small part of the truths about Brazil and its people that the Europeans had shared and built over the centuries, truths that largely had guided their actions in that part of the globe. Keywords: colonial habits, travel literature, travelers, colonial erotica, perspectives of tropical nature. 